2) Kutluoglu, E., J.R. Grace, K.W. Murchie and P.H. Cavanagh: Can. J. Chem. Eng., 61, 308-316 (1983)

3) Mathur, K.B. and N. Epstein : "Spouted Beds", pp. 263-264, Academic Press, New York (1974)

4) Sutanto, W., N. Epstein and J.R. Grace: Powder
Technol., 44, 205-212 (1985)

5) Uemaki, O., R. Yamada and M. Kugo: Can. J. Chem. Eng., 61, 303-307 (1983)

6) Zhao, J., C.J. Lim and J.R. Grace: Chem. Eng. Sci., 42, 2865-2875 (1987)

\title{
Regime Map of Binary Particle Mixture in a Spout-Fluid Bed
}

Toshifumi Ishikura

Dept. of Chem. Eng., Fukuoka Univ., Fukuoka 814-01

Key Words : Spout Fluid Bed, Binary Particle Mixture, Spout Fluidization, Regime Map

Experiments were carried out in a half-column of a spout-fluid bed, incorporating the central flow in addition to the auxiliary side flow. A binary particle mixture containing coarse and fine glass beads was investigated.

Six different flow patterns -- such as spouting with aeration (SA) and spout-fluidization (SF)-- were identified and mapped as regimes depending on the relative values of the central and the auxiliary air flow rates. Also, compared with the regime map for coarse particles only, it was recognized that a binary-particle mixture made the amount of gas flow to form SA or SF region small, but the operation range for SA or SF became narrow and the size segregation in the direction of radius appeared.

\section{無機多孔質薄膜に担持したアクリルアミドゲルによる 水/エタノールの分離特性 ${ }^{\dagger}$ \\ 一水の透過流束に及ぼすゲルの繰返し担持の効果一}

\section{迫原修治・立石 康 ·浅枝正司 \\ 広島大学工学部 第 3 類化学工学講座 ${ }^{\dagger \dagger}$}

無機多孔質薄膜の細孔内に代表的な親水性ゲルである アクリルアミドゲルを重合・担持した複合膜は, 水/有 機溶剂混合液の分離に対して高い分離性能を持つことを 報告してきた ${ }^{1,2,3)}$. この複合膜では, 膜上流側の溶剂濃 度の増加に伴ってゲルのネットワークが収縮し, 収縮し たネットワークによって溶剂分子の透過が阻止されるこ とで水の透過に対して高い選択性が期待できる.

てれまでに, 水/エタノール混合液の分離では水の透

†1993年 3 月 29日受理 ; 化学工学会第 25 回秋季大会 (東京, 1992年10月）にて発表

†† 724 東広島市鏡山 1-4-1
過の促進およびェタノールの透過の阻止に対してそれぞ れ最適なゲル組成，すなわちゲルを作製する際のモノマ 一および架橋剂濃度があること ${ }^{31}$, 分離性能の向上には ゲルの繰返し担持が有効なこと ${ }^{1,3)}$ を見出している. エタ ノールの透過阻止に最適なゲル組成があることは, ゲル 組成がネットワークの有効細孔径のみならずネットワー クの不均一構造, すなわち疎密化 ${ }^{4)}$ に大きく影響するこ とによって説明された ${ }^{3)}$. しかし，水の透過の促進に最 適なゲル組成があるてとについては十分に説明されてい ない，本研究では，ゲルを繰返し担持すると水の透過が 促進されること, 乙の現象は担持するゲルの水に対する 
Table 1 Composition of acrylamide gel

\begin{tabular}{|c|c|c|}
\hline & $\begin{array}{c}\text { Acrylamide } \\
{\left[\mathrm{mol} / \mathrm{m}^{3}-\mathrm{gel}\right]}\end{array}$ & $\begin{array}{l}\text { Methylenebisacrylamide } \\
{\left[\left[\mathrm{mol} / \mathrm{m}^{3}-\text { gel }\right]\right.}\end{array}$ \\
\hline Gel A & 1000 & 40 \\
\hline Gel B & 1000 & 80 \\
\hline
\end{tabular}

Promoter: TEMED $10 \mathrm{~mol} / \mathrm{m}^{3}-$ gel

Initiator: Ammonium Persulfate $50 \mathrm{~mol} / \mathrm{m}^{3}$

膨潤度と密接に関係することを見出したので報告する.

\section{1. 実 験}

膜の作製法および分離実験方法の詳細は前報 ${ }^{3)}$ に示す.

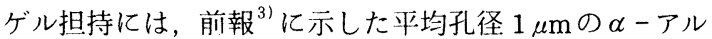
ミナ多孔質管 (外径 $10 \mathrm{~mm}$, 厚さ $1 \mathrm{~mm}$, 長さ $120 \mathrm{~mm}$ ) の外表面近傍に作製したシリカーアルミナ多孔晢薄膜を 用いた。 この無機薄膜の細孔内でアクリルアミド (モノマ 一)，およびメチレンビスアクリルアミド (架橋剤) を温 度 $70^{\circ} \mathrm{C}$ で共重合することによってゲルの担持を行った。 重合に際しては，少量の過硫酸アンモニウムおよびテト ラメチルエチレンジアミン(TEMED)をそれぞれ重合開 始剂および重合促進剤として用いた。ゲルの担持は分離 性能がほぼ变わらなくなるまで繰返した。分離実験は水 /エタノール混合液についてパーベーパレーション法で 行った. また, 分離温度は温度 $50^{\circ} \mathrm{C} て ゙$ 行った. 実験装置 および方法の詳細は既報 ${ }^{11}$ に示す.

\section{2. 実験結果および考察}

Fig. 1 は, ゲルの繰返し担持によるエタノールの透過 流束の変化の一例を, Table 1 亿示す 2 種類の組成のゲ ル AおよびBの場合について示したものである. てれら のゲルのモノマー濃度は同一であるが，ゲルBの架橋剤 濃度はゲル Aの 2 倍である. 図中の key は担持可数を表 す.ゲル A, B共に, 繰返し担持することによってエタノ 一ルの透過流束は単調に減少するが，5回担持後の透過 流束は架橋剂濃度の低いゲル A の方が大きい.

Fig. 2 に，ゲルA AよびBを繰返し担持した場合の水 の透過流束の変化を示す. 純水に対する透過流束はゲル の繰返し担持によってほぼ単調に減少しているが，架橋 剂濃度の高いゲルBの方が減少の度合いが大きい. しか し, 水/エタノール混合液に対しては, 水の透過流束は ゲル担持を繰返しても必ずしも減少しない．ゲル Aでは， 担持 2 回目までは単調に減少しているが， 3 回目以降は 逆に増加し，エタノール濃度が約 $20 \mathrm{~mol} \%$ 以上では 1 回 担持した場合よりあ大きくなっている．ゲルBでも担持 4 回目以降加若干ではあるが増加している.てのこと から, 水/エタノール混合液に対しては, ゲルを繰返し 担持すると水の透過が促進されるといえる.

Fig. 3 は，乙のことをより明確にみるために, Fig. 2

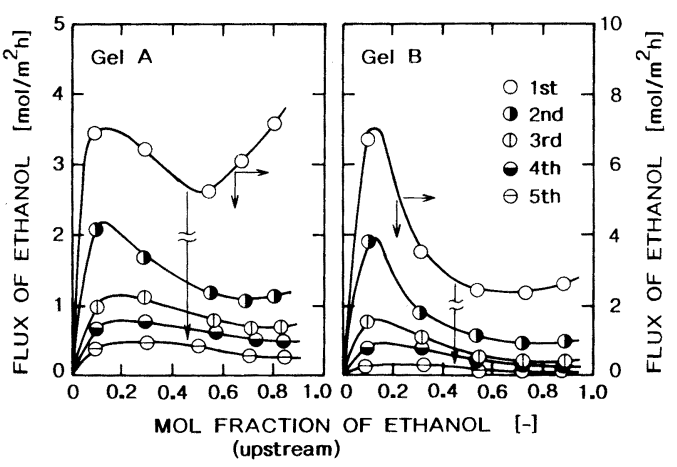

Fig. 1 Change of flux of ethanol by repeating the polymerization of gel

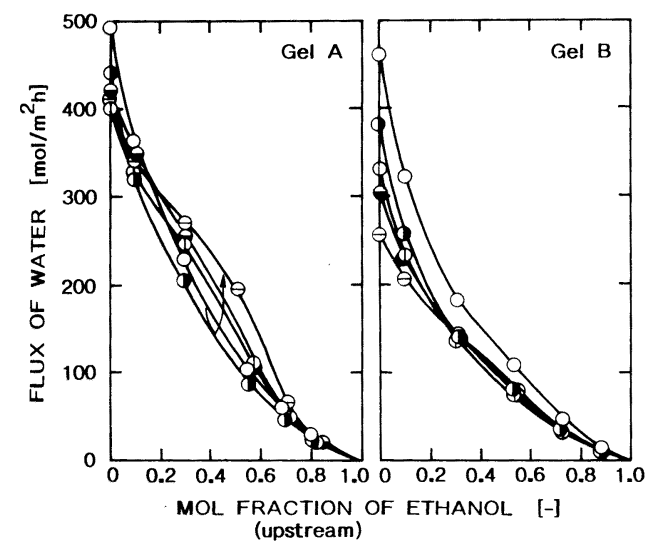

Fig. 2 Change of flux of water by repeating of the polymerization of gel (keys same as Fig.1)

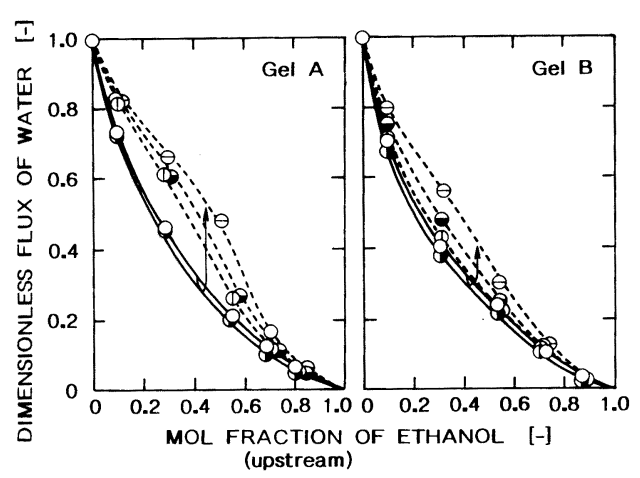

Fig. 3 Chage of dimensionless flux of water by repeating the polymerization of gel (keys same as Fig. 1)

の結果を純水の透過流束で規格化したものである. 図中 の破線はゲルの繰返し担持によって水の無次元透過流束 が増加している場合を示す。無次元透過流束でみると, ゲル A, B共に, 担持 3 回目以降のあののほうが水が透過 しやすくなっている. また, 架橋剤濃度の低いゲルAの 方がより透過しやすくなっている. 
Fig. 4 は，ゲル繰返し担持による透過側のエタノール 濃度の变化を示したものであり, 図中の破線はFig. 3 に 示してある水の無次元透過流束が增加した場合を表す. これからわかるように，透過液中のエタノール濃度が十 分低くなると水が透過しやすくなる，

これらの現象は他の組成のゲルを担持した場合であほ ぼ同様に現れ，ゲルを繰返し担持するてとによって分䧻 係数は著しく增加した.ゲル $\mathrm{A}$ および $\mathrm{B}$ を 5 回担持した 場合の分離係数, $x /(1-x) \cdot(1-y) / y$ は, 供給側エ夕, 一ル濃度 $80 \mathrm{~mol} \%$ でそれぞれ約 600 および 1200 である. ここで， $x$ および $y$ はそれぞれ供給側および透過側のエ タノールのモル分率である. 他の組成のゲルについての 分離係数は前報 ${ }^{31}$ に示す.

ゲル膜による水/エタノールの分離では, エタノール 濃度の増加に伴ってゲルネットワークが収縮し, 収縮し たネットワークによってェタノールの透過が阻止される と考えられる ${ }^{1,2,3)}$. しかし, Fig.1にみられるように, 1 回のゲル担持ではエタノールの透過を十分阻止できな いため, ゲル層内部にまで浸透したエタノールによって ゲル層全体が収縮すると考えられる，乙のような収縮は 水の透過に対しても抵抗となる。一方，ゲルの担持を繰 返すと先に形成されているネットワークと絡み合って新 たなネットワークが形成されるが，先に形成されている ネットワークが抵抗となるためにモノマーおよび架橋剂 はゲル層内部に十分浸透する前に重合し，ゲル層表面近 傍にネットワークの密な層が形成されると考えられる. このような密なネットワークの形成は, 水/エタノール の分離に抢いてェタノールの透過をより一層阻止するよ うになる.エタノールの透過が十分に阻止されほとんど 水のみが透過するようになると，担持回数が少なくエ夕 ノールの漏れが大きい場合に比べてゲル層内部のネット ワークは膨潤し，ゲル層内部では水に対する透過抵抗は 逆に小さくなり, 結果として水が透過しやすくなると考 えられる。

このように考えると，どの程度水が透過しやすくなる かは担持するゲルの水に対する膨潤度と密接に関係する ことになる．ゲル A および B の室温での水に対する膨潤 度, $\left(d / d_{0}\right)^{3}$ はそれぞれ 22.8 抢よび 16.3 であり, 架橋剤 濃度の低いゲル Aの方が膨潤度が大きい。乙れは既報 ${ }^{1,2)}$ と同様に円柱状ゲルを用いて測定したあのであり， $d_{0}$ お よび $d$ はそれぞれ乾燥ゲルの径掞よび平衡膨潤時の径で ある.ゲルA捛よびBの繰返し担持による水の透過しや すさを比較すると, Fig. 3 亿みられるように膨潤度の大 きいゲル Aの方がゲル B よりあ水の無次元透過流束の増 加が大きくなっている. また, 架橋剂濃度が低いゲル A では, 繰返し担持による純水の透過流束の減少が小さい

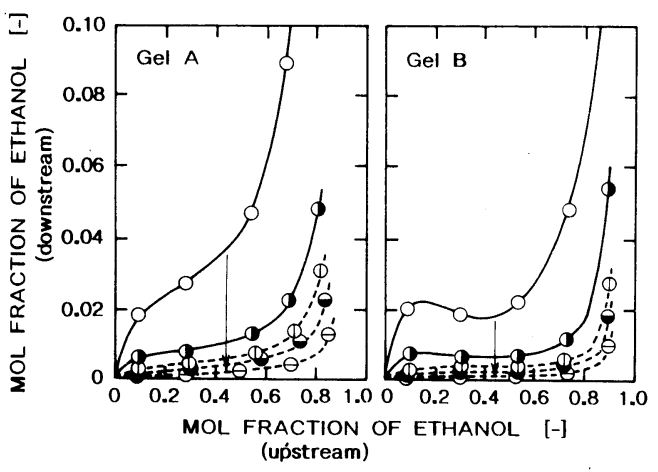

Fig. 4 Change of ethanol concentration in the downstream by repeating the polymerization of gel (keys same as Fig. 1)

ために Fig. 2 にみられるようにゲルBに比べて水の透過 流束そのあのが著しく增加したと考えられる.

しかし，膨潤度が大きいゲル A は，ゲル層内部での大 きな膨潤力が表面近傍の密なネットワークをあ押し拡げ ようとするためにエタノールの透過を十分に阻止するこ とが逆に困難になり，Fig.1亿みられるようにエタノ一 ルの透過流束はゲル B ほど低下していない．水に対する 膨潤度がさらに大きく，エ夕ノールの透過が十分に抑え られなくなると，ゲル層内部のネットワークが十分膨潤 できず，水の透過の促進はかえって期待できないと予想 される，膨潤度がゲルAよりも大きい，架橋剤濃度が $30 \mathrm{~mol} / \mathrm{m}^{3}$ のゲルの場合には, 繰返し担持してもエ夕, 一ルの透過流束が十分に減少せず，ゲル A ぼ水の透過 流束が増加しなかった。

これらのことから，水の透過の促進に対して最適な架 橋剂濃度があるといえる．モノマー濃度 $2000 \mathrm{~mol} / \mathrm{m}^{3}$ の ゲルを担持した場合にも同様な傾向がみられ，架橋剂濃 度 $40 \mathrm{~mol} / \mathrm{m}^{3}$ の場合には分離係数 3000 を越える非常に 高い選択性が得られた。しかし，モノマー濃度 $1000 \mathrm{~mol} /$ $\mathrm{m}^{3}$ のゲルに比べて水に対する膨潤度が小さいため, 絽返 し担持しても水の透過流束の増加はみられなかった。し たがって，前報”) で示したように，水の透過の促進に対 しても最適なゲル組成があるといえる.

\section{Literature cited}

1) Sakohara, S., F. Muramoto, T. Sakata and M. Asaeda: J. Chem. Eng. Japan, 23, 40-45 (1990)

2) Sakohara, S., F. Muramoto, S. Sakai, M. Yoshida and M. Asaeda: "Polymer Gels", p.161, Plenum Press, New York (1991)

3) Sakohara, S., Y. Maekawa, Y. Tateishi and M. Asaeda: J. Chem. Eng. Japan, 25, 598-603 (1992)

4) Tanaka, T.: Scientific American, 244, 110-123(1981) 


\section{Separation Properties of Water/Ethanol Mixtures by}

Acrylamide Gel Polymerized in Pores of a Thin Ceramic Membrane

- Effects of repeating polymerization of gel on water flux -

Shuji Sakohara, Yasushi Tateishi and Masashi Asaeda

Dept. of Chem. Eng., Hiroshima Univ., Higashi-Hiroshima 724

Key Words : Membrane Separation, Acrylamide Gel, Ceramic Membrane, Pervaporation, Swelling, Water, Ethanol

Separation properties of water/ethanol mixtures by acrylamide gel polymerized repeatedly in the pores of silica-alumina thin membrane were examined. By repeating the polymerization of gel, the flux of ethanol decreases monotonously, while the permeation of water is promoted as the flux of ethanol becomes sufficiently small. As a result, extremely high separation performance can be obtained. The increment of water flux is closely related to the swelling degree of the gel in water, and an optimum gel composition for the promotion of water permeation exists.

\section{界面活性剂被覆リパーゼを用いたグリセリドのエステル合成反応 ${ }^{\dagger}$ \\ 後藤宗治・後藤雅宏・中塩文行 \\ 九州大学工学部 応用物質化学科 ${ }^{\dagger \dagger}$ \\ 畑中千秋・原口俊秀 \\ 北九州工業高等専門学校 化学工学科 $^{\dagger \dagger \dagger}$}

\section{緒 言}

酵素は触媒能, 反応特異性が高く, 酵素を利用するこ とによって有用物質を高選択的に合成することが可能と なる．特に酵素機能を損なわずに有機溶媒中で反応を行 うことができれば，平衡が加水分解側から合成側にシフ トするため，エステル，ペプチドの合成，ステロイドの 修飾, 油脂の改質などへの利用が考えられる。しかしな がら，一般に酵素は水溶性であり，過剰の水の存在下で 安定である。したがって水難溶性物質を基質として用い る有機溶媒中における酵素反応の場合，何らかの工夫が

$\dagger$ 1993年 2 月 1 日受理 ; 化学工学会第 58 年会 (鹿児島, 1993 年 3 月）にて一部発表

†† $\mathbf{T} 812$ 福岡市東区箱崎 6-10-1

†† $\mathbf{T} 803$ 北九州市小倉南区志井 5-20-1
必要となる。なかでも界面活性剂で酵素を被覆する界面 活性剂被覆法が有効であるととが報告されている ${ }^{2,6,7)}$.

前報に打いて ${ }^{4)}$ 我々は，界面活性剤被覆りパーゼを用 た有機溶媒中でのトリグリセリドの加水分解反応を検討 し, 選択的な加水分解が可能となること, さらに加水分 解速度および転化率が粉末酵素の場合に比べ非常に増大 することを報告した．

そこで本研究では，界面活性剂被覆リパーゼを用いた グリセリンとオレイン酸からの選択的なトリグリセリド の合成反応について検討した。

\section{1. 実験}

1.1 試薬

Candida cylindracea 起源のリパーゼはSigma 社より 購入し, Pseudomonas sp. (リパーゼP), Mucor 